\title{
Investigation of The Efficacy of Kinesiological Banding in Pregnancy-Related Carpal Tunnel Syndrome
}

\section{Gebelik Illişkili Karpal Tünel Sendromunda Kinezyolojik Bantlama Uygulamasının Etkinliğinin Araştırılması}

Meryem Kosehasanogullari ${ }^{1}$, Nihal Yilmaz ${ }^{1}$,

Ahmet Karakoyun²,

Irem Senyuva ${ }^{3}$,

Seyfullah Gorkem Kosehasanogullari ${ }^{4}$

Usak Training and Research Hospital Department of Physical Medicine and Rehabilitation, Usak, Turkey

${ }^{2}$ Aksaray Universty Medical Faculty Department of Physical Medicine and Rehabilitation, Aksaray, Turkey

${ }^{3}$ Usak Training and Research Hospital Department of Obstetrics and Gynecology Clinics, Usak, Turkey

${ }^{4}$ Usak Training and Research Hospital Department of Neurology, Usak, Turkey

Geliş Tarihi/Received: 24 April 2019 Kabul Tarihi/Accepted: 22 August 2019

Address correspondence to: Ahmet Karakoyun, Aksaray Universty Medical Faculty Department of Physical Medicine and Rehabilitation, Aksaray, Turkey e-mail: furkankk42@hotmail.com

\section{ORCID}

Meryem Kosehasanogullari

https://orcid.org/0000-0001-5893-0823 Nihal Yilmaz

https://orcid.org/0000-0001-9817-0507 Ahmet Karakoyun

https://orcid.org/0000-0001-8288-9744 Irem Senyuva

https://orcid.org0000-0003-1364-5644 Seyfullah Gorkem Kosehasanogullari

https://orcid.org/0000-0002-4797-5409

\section{Öz}

Amaç: Bu çalışmada gebelikle ilişkili karpal tünel sendromunda kinezyolojik bantlamanın semptomla üzerine etkisinin araştırılması planlandı.

Hastalar ve Yöntem: Çalışmaya karpal tünel sendromu nedeniyle Fizik Tedavi ve Rehabilitasyon Kliniğine başvuran ve elektromiyografi ile karpal tünel sendromu tanısı alan, kayıtlarında visuel ağrı skoru, Kısa Form-36, Boston Karpal Tünel Anketi ve Pittsburgh Uyku Kalite Indeksi değerlerine başvuru ve takip esnasında eksiksiz ulaşılabilen hastalar dahil edildi.

Bulgular: Her iki grupta da ilk visuel ağrı skoru gündüz-gece ve son visuel ağrı skoru gündüz-gece ve ilk ve son Pittsburgh Uyku Kalite Indeksi arasında anlamlı fark saptandı $(p<0,05)$. Her iki grupta da Boston Semptom Şiddeti Skalasında anlamlı düzelme saptanırken, Boston Fonksiyonel Kapasite Skalasında anlamlı fark saptanmadı. Gruplar arası karşılaştırmada ise kinezyolojik bantlama uygulanan hastalarda visuel ağrı skoru gündüz, Kısa Form-36 ağrı parametresi ve Boston Semptom Şiddeti Skalasındaki azalma istatistiksel olarak anlamlı saptandı.

Sonuç: Çalışmamızda kinezyolojik bantlamanın el-el bilek istirahat splintine üstünlüğü net olarak gösterilememesine rağmen ağrı ve semptomlarda azalma ve uyku kalitesinde artış gözlenmiştir. Gebelikte tedavi seçeneklerinin az olması nedeniyle istirahat splintine yanıt alınamayan hastalarda kinezyolojik bantlama aklımızda bulunmalıdır.

Anahtar Kelimeler: Gebelik, karpal tünel sendromu, kinezyolojik bantlama

\section{Abstract}

Aim: The aim of this study was to investigate the effects of kinesiological banding on symptoms in carpal tunnel syndrome associated with pregnancy.

Patients and Methods: Patients who were admitted to the Physical Therapy and Rehabilitation Clinic due to carpal tunnel syndrome and who were diagnosed with carpal tunnel syndrome by electromyography and who were able to reach the visuel analog score, Short Form-36, Boston Carpal Tunnel Questionnaire and Pittsburgh Sleep Quality Index values were included in the study.

Results: In both groups, there was a significantly difference between the first visuel analog score day-night and the last visuel analog score day-night and first and last Pittsburgh Sleep Quality Index $(p<0,05)$. While there was a significantly improvement in the Boston Symptom Severity Scale, there was no significantly difference in Boston Functional Capacity Scale. In the comparison between the groups, visuel analog score day, Short Form-36 pain parameter and decrease in Boston Symptom Severity Scale were found statistically significant.

Conclusions: In our study, although the superiority of kinesiological banding on hand-wrist rest splint could not be clearly shown, decreased pain and symptoms and an increase in sleep quality were observed. The kinesiological banding should be in mind in patients who have no response to resting splint because of low treatment options during pregnancy.

Key words: Pregnancy,carpal tunnel syndrome, kinesiological banding

\section{INTRODUCTION}

Carpal tunnel syndrome (CTS) is the most common entrapment neuropathy produced by compression of the median nerve at the wrist $(1,2)$. It is characterized by numbness, tingling, and pain on the first three fingers and radial half of the fourth finger
Cite this article as: Kosehasanogullari M, Yilmaz N, Karakoyun A, Senyuva I, Kosehasanogullari SG. Investigation of The Efficacy of Kinesiological Banding in Pregnancy-Related Carpal Tunnel Syndrome. Selcuk Med J 2020;36(2): 109-115
Disclosure: None of the authors has a financial interest in any of the products, devices, or drugs mentioned in this article. The research was not sponsored by an outside organization. All authors have agreed to allow full access to the primary data and to allow the journal to review the data the primary data and to allow the journal to review the data if requested. 
$(3,4)$. Although many factors cause CTS, it is mostly idiopathic. While only $4 \%$ of the general population suffers from CTS, the prevalence rises to $10 \%$ in the working population $(5,6)$. The decrease in the size of the carpal tunnel or increase in the occupied volume inside the carpal tunnel causes CTS. Obesity, diabetes, and rheumatoid arthritis are among the risk factors for CTS $(4,7,8)$.

CTS has long been associated with pregnancy. Pregnancy-associated CTS is often bilateral and usually occurs in the last trimester (9-13). Although the actual cause of pregnancy-related CTS is unknown, it is considered to be caused by local edema in the carpal tunnel due to hormonal changes (9-14). Prevalence of pregnancy-related CTS is highly variable (11-14). Patients not indicating their symptoms and the physicians not questioning about patients' symptoms are considered to be the most crucial reason for this variability (15). Kinesiology taping is a taping technique based on the body's natural healing developed by chiropractor Kenzo Kase as an alternative to classical taping that restricts movement. Kinesiology taping helps restore muscle function by strengthening weak muscles or release muscular spasm and normalize fascia functions as well as helps joints return to their normal position by corrective application techniques. It also alleviates pain by reducing neurological pressure $(16,17)$. There are Kinesio-therapies available to reduce pregnancyrelated low back pain and improve life and sleep quality (18). There are very few studies on kinesiology taping and kinesiology taping in CTS (19-21), and to the best of our knowledge, there is no study using kinesiology taping technique in pregnancy-related CTS.

In this study, we planned to investigate the effects of kinesiology taping on the symptoms of pregnancyrelated CTS since treatment options are limited in pregnant women.

\section{PATIENTS AND METHOD}

In this retrospective study, the patients who were referred from Obstetrics and Gynecology Clinics to Physical Therapy and Rehab (PTR) outpatient clinics due to pregnancy-related CTS during 2016-2017 were screened. Out of the screened patient records, patients who had complete pain level (Visual pain score (VAS) and Boston Carpal Tunnel Questionnaire (BCTQ) and Pittsburgh Sleep Quality Index (PSQI) values available at admittance and follow-up were selected from pregnant women who were admitted to PTR outpatient clinic due to CTS and diagnosed with CTS by electromyography (EMG) and included in the study. Patients with a history of CTS, hand-wrist surgery, trauma, rheumatic disease, preeclampsiaeclampsia, diabetes mellitus, and hyperthyroidismhypothyroidism were excluded from the study. Out of the patients who met study criteria, those who received at least four sessions of Kinesiotape applied on the hand-wrist area for 21 days formed Kinesiotape treatment group (KTTG) and those who only wore a hand-wrist splint at night formed Control group (CG).

Kinesiotape treatment for CTS applied by physiatrists in PTR outpatient clinics is standard. It is applied for four sessions using Kinesio-tape (KINESIO TEX GOLD 5 CMX5 M, USA). The Kinesio-tape is applied to dry and clean skin by moderate stretching to the second and third metacarpophalangeal joints to a distance of $5 \mathrm{~cm}$ below the medial epicondyle when hand-wrist is in 30-degree extension, forearm in supination and elbow in full extension. For space correction, the middle of the tape is stretched to the volar surface of the wrist which is half the length of the wrist circumference, with the anchor ends of the tape applied with no stretch (Figure 1).

\section{Standard parameters used in clinical follow-up: Pain}

Visual analog score (VAS) was used to measure

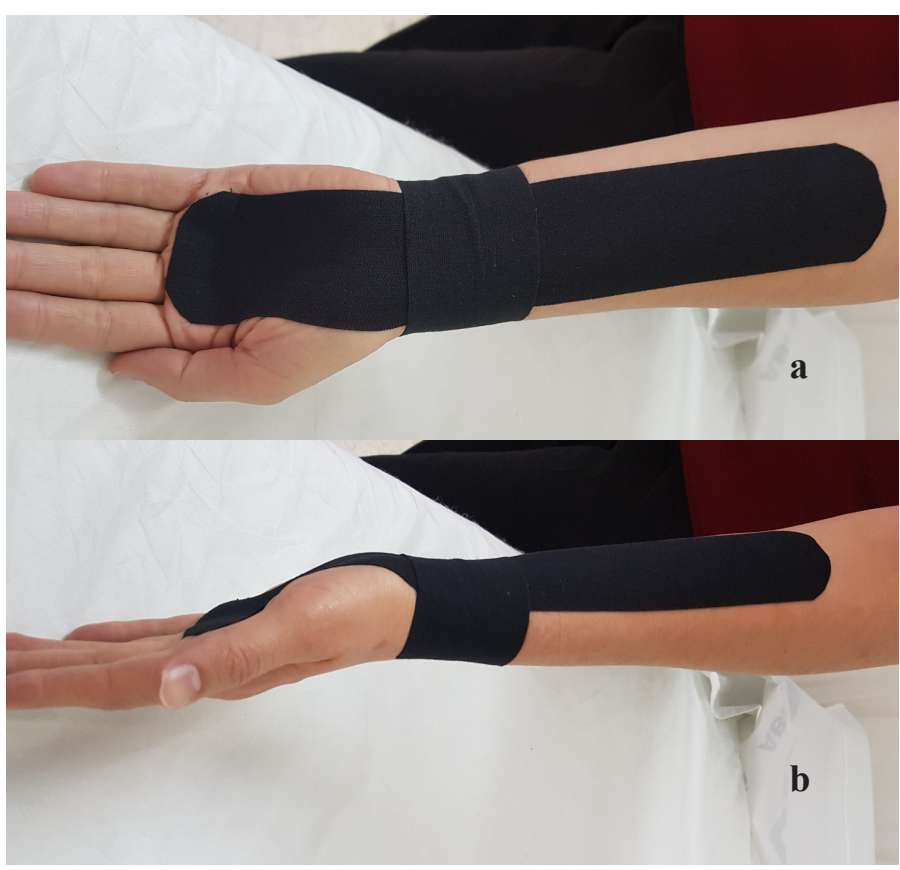

Figure 1a and 1b. Application of Kinesiology taping 
pain intensity. It was presented as a $10-\mathrm{cm}$ horizontal line on which the patient's pain intensity is represented by a point between the extremes of $0=$ no pain at all and $10=$ worst pain imaginable. Patients indicated their pain intensity on a $0-10$ rating scale.

\section{Boston Carpal Tunnel Questionnaire (BCTQ)}

Boston Carpal Tunnel Syndrome Questionnaire (BCTQ) is a questionnaire developed by Levine et al. in 1993, consisting of two scales: Boston symptom severity scale (BSSS) and Boston functional status scale (BFSS) (22). BCTQ had 8 questions evaluating the degree of difficulty experienced during daily living activities and BSSS had 11 questions related to disease symptoms such as pain, weakness, numbness and tingling with each activity being scored between 1 and 5 ( 1 being the lowest and 5 being the highest level of symptom severity or degree of difficulty to perform an activity). Mean score is calculated by dividing the total score by the number of questions. Higher scores indicate greater symptom severity (23). The validity and reliability study of the Turkish version of BCTQ was performed in 2001 by Heybeli et al. (24).

\section{Short Form-36 (SF-36)}

Short Form 36, which is a generic quality of life measure, was developed and introduced by the Rand Corporation in 1992 (25). The scale was intended to be short and easy to use in a broad spectrum of health status. The scale consists of 36 items, which measure eight domains: Physical function (10 items), social function (two items), role limitations due to physical health problems (four items), role limitations due to emotional problems (three items), mental health (five items), energy/vitality (four items), pain (two items) and general health perception (five items) (25). The scale is evaluated based on the last four weeks. The evaluation is made in the form of 'Likert' (with three or with six) except for the fourth and fifths items where yes/no format is used (25). The subscales evaluate health within a range of 0 to 100 points with 0 point indicating poor health and 100 points indicating functional health status. Reliability and validity of the Turkish version of SF-36 was performed by Koçyiğit et al. (26).

\section{Pittsburgh Sleep Quality Index (PSQI)}

Pittsburgh Sleep Quality Index (PSQI) is a selfrated screening and evaluation test developed by Buysse et al. in 1989 that provides detailed information on the sleep quality and type and severity of sleep disturbances over a 1-month time interval (27). The reliability and validity study of the Turkish version of PSQI was performed by Ağargün et al. (1996)
(Cronbach's alfa=0.80) (28). The index consisting of a total of 24 questions gives scores for seven subscales. These include Subjective Sleep Quality, Sleep Latency, Sleep Duration, Habitual Sleep Efficiency, Sleep Disturbances, Use of Sleep Medication, and Daytime Drowsiness. In the 32nd index, there are also five questions that request the evaluation of the person's bedmate, though not scored. Each question is rated on a scale of 0 to 3 . The sum of the scores for the seven subscales gives the total PSQI score. The total PSQI score ranges from 0-21. A PSQI score of less than or equal to 5 indicates "good sleep quality," and a PSQI score of above 5 indicates "poor sleep quality." A PSQI score of above 5 indicates that the person suffers severely from at least two subscales or mildly to moderately from more than three subscales.

\section{Statistical Analysis}

Statistical analysis was performed using SPSS 16 (SPSS Inc. Released 2007. SPSS for Windows, Version 16.0. Chicago, SPSS Inc.) software. The appropriateness of the obtained data to normal distribution was determined by the Kolmogorov Smirnov test. Since there is the normal distribution, Student "t" test was used for inter-group comparisons, and Paired Samples t-test was used for intragroup evaluations. For statistical comparisons, the significance is considered at $p<0.05$.

\section{RESULTS}

The results were screened; 25 patients were evaluated in KTTG, and 22 patients were evaluated in CG. The mean age of patients was $28.96 \pm 6.3(18-37)$ in KTTG and $27.4 \pm 4.6$ (18-37) in CG. Mean gestational week was $31,1 \pm 2,8$ (27-35) in KTTG and $31 \pm 2,9$ (26-35) in CG. There was no significant difference in age and the gestational week between two groups ( $p>$ 0.05). Demographic characteristics and sociocultural characteristics of the patients in both groups were not statistically significant. Patients' demographic data in both groups were presented in Table 1. In both groups, there was a statistically significant difference in VAS values during the day and night evaluated at baseline vs. at the end of the study. Inter-group comparisons showed a statistically significant difference in KTTG in terms of daytime VAS values but no statistically significant difference in nighttime VAS values. Both groups showed a statistically significant difference in terms of PSQI values in the first vs. last evaluation, while no significant difference was found between the groups. Both groups and inter-group evaluation showed a statistically significant improvement in 
Table 1. Characteristics of study population

\begin{tabular}{|c|c|c|c|}
\hline & KTTG (n:25) & CG(n:22) & $\mathbf{p}$ \\
\hline Age (year) & $28.9 \pm 6.3$ & $27,4 \pm 4,6$ & 0,46 \\
\hline Gestational week & $31,1 \pm 2,8$ & $31,0 \pm 2,9$ & 0,85 \\
\hline Education $(n)$ illiterate/low/medium/high & $3 / 12 / 8 / 2$ & $6 / 6 / 5 / 5$ & 0,06 \\
\hline Employment status ( $n$ ) Housewife/Officer/Employment/Self-employment & $17 / 2 / 2 / 4$ & $17 / 0 / 1 / 4$ & 0,07 \\
\hline
\end{tabular}

KTTG: Kinesio-Tape treatment group , CG: Control group

Boston symptom severity scale, whereas there was no significant improvement in functional status scale.

When the SF-36 values of the patients in KTTG and CG were examined, KTTG showed statistically significant $(p<0.05) p$ values in terms of vitality only in the first and last evaluation. The intergroup comparison showed a statistically significant difference in pain parameter, whereas no statistically significant difference was found in terms of other parameters ( $p>0.05)$. VAS pain score, SF-36, PSQI, and Boston Carpal Tunnel Questionnaire values of the patients in both groups are presented in Table 2.

\section{DISCUSSION}

Kinesiology taping is an additional treatment modality used in the treatment of some musculoskeletal problems in addition to other treatment methods. It acts by decreasing the neurological pressure on the pain receptors, strengthening weak muscles, release muscular spasm, and normalize fascia functions
$(16,17)$. The hand-wrist splint is a noninvasive treatment method that is widely used in CTS. The purpose of the splint is to alleviate pain and numbness by reducing hand-wrist movements. It also prevents excessive flexion-extension of the wrist during sleep, preventing median nerve compression and tension (29-33). CTS has long been associated with pregnancy. Pregnancy-associated CTS is often bilateral and usually occurs in the last trimester (913). Although the actual cause of pregnancy-related CTS is unknown, it is considered to be caused by local edema in the carpal tunnel due to hormonal changes (9-14). Prevalence of pregnancy-related CTS is highly variable (11-14). Patients not indicating their symptoms and the physicians not questioning about patients' symptoms are considered to be the most crucial reason for this variability (15).

In the literature, there are very few studies on kinesiology taping (19-21). There is no study using kinesiology taping technique in pregnancy-related

Table 2. Comparison of outcomes parameters

\begin{tabular}{|c|c|c|c|c|c|c|}
\hline & Baseline & $\begin{array}{c}\text { KTTG } \\
(n: 25) \\
\text { End of the study }\end{array}$ & $\mathbf{p}$ & Baseline & $\begin{array}{c}\text { CG } \\
(n: 22) \\
\text { End of the study }\end{array}$ & $\mathbf{p}$ \\
\hline \multicolumn{7}{|l|}{ VAS } \\
\hline Day & $6.2 \pm 2.4$ & $3.8 \pm 2.3$ & 0.001 & $4.0 \pm 2.4$ & $3.4 \pm 2.4$ & 0.007 \\
\hline $\begin{array}{l}\text { Night } \\
\text { SF-36 }\end{array}$ & $5.6 \pm 2.6$ & $3.4 \pm 2.1$ & & $3.2 \pm 2.9$ & $2.2 \pm 2.3$ & \\
\hline Physical functioning & $50.2 \pm 21.9$ & $55.0 \pm 19.4$ & 0.132 & $59.7 \pm 28.5$ & $63.4 \pm 26.1$ & 0.052 \\
\hline RLdPH & $40.0 \pm 38.1$ & $50.0 \pm 39.5$ & 0.153 & $59.0 \pm 37.4$ & $63.6 \pm 35.9$ & 0.102 \\
\hline Pain & $48.2 \pm 26.3$ & $64.2 \pm 23.1$ & 0.007 & $67.8 \pm 25.0$ & $68.2 \pm 24.0$ & 0.655 \\
\hline General Health & $51.8 \pm 19.9$ & $54.8 \pm 18.9$ & 0.112 & $58.4 \pm 17.9$ & $58.8 \pm 18.7$ & 0.414 \\
\hline Energy/fatigue & $42.4 \pm 17.0$ & $49.2 \pm 18.0$ & 0.017 & $61.8 \pm 22.0$ & $62.7 \pm 21.5$ & 0.157 \\
\hline Social Function & $59.4 \pm 26.4$ & $64.7 \pm 21.9$ & 0.179 & $74.0 \pm 22.8$ & $76.9 \pm 20.1$ & 0.317 \\
\hline Emotional well-being & $42.6 \pm 39.1$ & $53.3 \pm 44.1$ & 0.176 & $57.5 \pm 42.6$ & $59.0 \pm 41.1$ & 0.317 \\
\hline Mental Health & $60.3 \pm 17.3$ & $60.0 \pm 17.4$ & 0.950 & $71.3 \pm 19.0$ & $73.0 \pm 18.2$ & 0.109 \\
\hline $\begin{array}{l}\text { PUKI } \\
\text { BCTQ }\end{array}$ & $7.2 \pm 3.4$ & $6.1 \pm 2.7$ & 0.002 & $6.0 \pm 2.6$ & $5.3 \pm 2.4$ & 0.006 \\
\hline BSSS & $29.0 \pm 8.1$ & $23.0 \pm 6.6$ & 0.157 & $17.6 \pm 6.6$ & $16.5 \pm 6.5$ & 0.296 \\
\hline BFSS & $16.1 \pm 6.4$ & $14.0 \pm 5.0$ & & $11.7 \pm 5.6$ & $10.0 \pm 3.2$ & \\
\hline
\end{tabular}

KTTG: Kinesio-Tape treatment group, CG: Control group, VAS: Visual analog score, SF-36: Short Form 36, PUKI: Pittsburgh Sleep Quality Index, BCTQ:

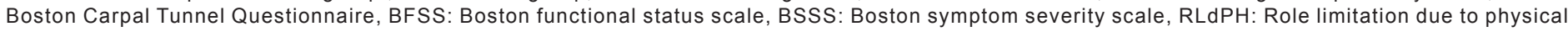
health 
CTS. In this study, we aimed to investigate the effects of kinesiology taping on the symptoms of pregnancyrelated CTS with a retrospective study since treatment options are limited in pregnant women. Park et al. investigated the effect of kinesiology taping on electrophysiological modifications in CTS (19). Twenty female patients between the ages of 40 and 60 were included in the study with the first group receiving kinesiology taping twice a week for four weeks. The second group did not receive any treatment. While the evaluation performed after the fourth week revealed a significant difference between distal motor latency and sensory nerve conduction velocity, no difference was found between the compound muscle action potential and sensory nerve action potential (SNAP) after four weeks of treatment. Another study of 21 healthy sports(wo)men demonstrated that kinesiology taping applied on the wrist had provided short-term improvement in proprioception and hand grip, but had been ineffective not in long-term follow-up (30). Güner et al. compared low-dose laser and kinesiology taping for the treatment of CTS (20). Sixty-four hands were included in the study and randomized into three groups. The first group was treated with low-dose laser, the second group was treated with kinesiology taping, and low-dose laser and the third group was treated with sham laser. Patients' VAS, BCTQ, hand grip strength, and finger pinch strength were evaluated at the third and 12th weeks after the treatment. Comparison of the groups revealed significant improvement in the post-treatment evaluation parameters compared to pre-treatment evaluation parameters in Group 1 vs. Group 2. Comparison of Group 1 and 2 revealed no significant difference between post-treatment evaluation parameters at week 3 , whereas the evaluation performed at week 12 showed a significant improvement in finger pinch strength and hand grip strength in Group 2.

Öncü et al. randomized the patients with idiopathic CTS to four groups and applied kinesiology taping to the first group, a resting splint to the second group, a combination of kinesiology taping and resting splints to the third group with the fourth group serving as control (21). Kinesiology taping was applied once a week for 25 days. Significant improvement was observed in the symptoms of the group using kinesiology and resting splint; the evaluation performed at Month 2 showed significant improvement in the group using only kinesiology taping and, in the group, using the only splint compared to the control group, but no longterm difference was found between groups. Mamente et al. randomized the patients with idiopathic CTS to two groups; then, the first group was given a resting splint, and the second group did not receive any treatment. Significant improvement was observed in the symptoms of the group using a resting splint (34). In another randomized con-trolled study, patients were divided into 3 groups and applied a resting splint to the first group, a combination of local steroid injection and resting splints to the second group and surgical treatment to the third group. Significant improvement in nerve conduction velocities was found in all three groups in the short term. They stated that conservative methods in the treatment of mild and moderate CTS could provide a comparable improvement with surgery (35).

In our study, 25 patients were evaluated in KTTG, and 22 patients were evaluated in CG. In both groups, there was a statistically significant difference in VAS values during the day and night, PSQI and SPF-36 vitality evaluated at baseline and at the end of the study. Inter-group comparisons showed a statistically significant difference in KTTG in terms of daytime VAS values and SPF-36 pain parameters but no statistically significant difference in night-time VAS values, PSQI, or other SPF-36 parameters. Both groups and intergroup evaluation showed a statistically significant improvement in Boston symptom severity scale, whereas there was no significant improvement in functional status scale. Our study had several limitations, the retrospective nature of our study is the most critical limitation. The second limitation of this study is the absence of electromyography studies. Electromyography is widely using to evaluate the effectiveness of therapeutic measures (36) also, previous studies showed the relationship between electromyographic data and surgical success in patients with CTS (37). In the literature, this is the first study on kinesiology taping during pregnancy.

\section{CONCLUSION}

Kinesiology taping releases the pressure on the nerve by expanding the carpal tunnel, alleviating the pain. Although the kinesiology taping in pregnancy-related CTS was not superior to resting splint except for the pain relief in this study, we think that the kinesiology taping can be alternative to resting splint in pregnant patients. This subject needs more prospective randomized controlled trials with larger sample size.

Conflict of interest: Authors declare that there is no conflict of interest between the authors of the article. 
Financial conflict of interest: Authors declare that they did not receive any financial support in this study.

Address correspondence to: Ahmet Karakoyun, Aksaray Universty Medical Faculty Department of Physical Medicine and Rehabilitation, Aksaray, Turkey

Telephone: +90530656 6550

e-mail: furkankk42@hotmail.com

\section{REFERENCES}

1. Heebner ML, Roddey TS. The effects of neural mobilization in addition to standard care in persons with carpal tunnel syndrome from a community hospital. J Hand Ther 2008;21:229-40.

2. Gelberman RH, Rydevik BL, Pess GM, et al. Carpal tunnel syndrome. Orthopedic Clinics of North America 1998;19:11524.

3. Dawson DM. Entrapment neuropathies of the upper extremities. N Engl J Med 1993;329:2013-8.

4. Ibrahim I, Khan WS, Goddard N, et al. Carpal tunnel syndrome: A review of the recent literature. Open Orthop $\mathrm{J}$ 2012;6:69-76.

5. Atroshi I, Gummesson C, Johnsson R, et al. Prevalence of carpal tunnel syndrome in a general population. JAMA 1999;282:153-8

6. Spahn G, Wollny J, Hartmann B, et al. Metaanalysis for the evaluation of risk factors for carpal tunnel syndrome (CTS) Part II. Occupational risk factors. Z Orthop Unfall 2012;150:516-24.

7. Baker, Nancy A. The comparative effectiveness of combined lumbrical muscle splints and stretches on symptoms and function in carpal tunnel syndrome. Archives of physical medicine and rehabilitation 2012;93(1):1-10.

8. Karahan AY, Arslan S, Özen K, et al. Türk toplumunda median ve ulnar sinirlerin ultrasonografik değerlendirilmesi ve antropometrik ölçümlerle ilişkisi. Ege Tıp Bilimleri Dergisi 2018;1(1):13-8.

9. Osterman M, Ilyas AM, Matzon JL. Carpal tunnel syndrome inpregnancy. Orthop Clin North Am 2012;43:515-20.

10. Finsen V, Zeitlmann $H$. Carpal tunnel syndrome during pregnancy. Scand J Plast Reconstr Surg Hand Surg 2006;40:41-5.

11. Mondelli M, Rossi S, Monti E, et al. Prospective study of positive factors for improvement of carpal tunnel syndrome in pregnant women. Muscle Nerve 2007; 36:778-83.

12. Ablove $\mathrm{RH}, \mathrm{Ablove} \mathrm{TS}$. Prevalence of carpal tunnel syndrome inpregnant women. WMJ 2009;108:194-6.

13. Stolp-Smith KA, Pascoe MK, Ogburn PL Jr. Carpal tunnel syndrome in pregnancy: Frequency, severity, and prognosis. Arch Phys Med Rehabil 1998;79:1285-7.

14. Padua L, Aprile I, Caliandro $P$, et al. Symptoms and neurophysiological picture of carpal tunnel syndrome in pregnancy. Clin Neurophysiol 2001;112:1946-51.

15. Sapuan J, Yam KF, Noorman MF, et al. Carpal tunnel syndrome in pregnancy - you need to ask. Singapore Med J 2012;53:671-5.

16. Zajt J, Rajkowska E. Application of kinesio taping for treatment of sports injuries. Medsportpress Research Yearbook (17397988) 2007;13(1):130-4.

17. Khanov L. Kinesio taping, Part 1: An overview of its use in athletes. Athletic Therapy Today 2007;12(3):17-8.

18. Şenyuva İ, Kösehasanoğulları M, Yılmaz N, et al. Üçüncü trimestirde gebelikle ilişkili bel ağrısının azaltılması, yaşam ve uyku kalitesini arttırımasında Kinesio-terapi ve ev egzersizinin karşılaştırılması. CBU-SBED, 2018;5(3):120-5.

19. Park YD, Park YJ, Park SS, et al. Effects of taping therapy for carpal space expansion on electrophysiological change in patients with carpal tunnel syndrome. J Exerc Rehabil 2017;30:13(3):359-62.

20. Güner A, Altan, L, Kasapoğlu A. The effectiveness of the low-power laser and kinesiotaping in the treatment of carpal tunnel syndrome, a pilot study. Rheumatology International 2018.

21. Öncü J, İlişer R, Yılmaz $F$, et al. Karpal tünel sendromu tedavisinde kinezyo bantlama tekniğinin hastalık semptomları, el fonksiyonu ve kavrama gücüne etkisi: Tek kör randomize kontrollü çalışma. Türk Fiz Tıp Rehab Derg 2014;60(1):43-S51.

22. Levine DW, Simmons BP, Koris MJ, et al. A self-administered questionnaire for the assessment of severity of symptoms and functional status in carpal tunnel syndrome. JBJS 1993;75(11):1585-92.

23. Leite JCC, Jerosch-Herold C, Song F. A systematic review of the psychometric properties of the Boston carpal tunnel questionnaire. BMC Musculoskelet Disord 2006;7:78.

24. Heybeli N, Özerdemoglu RA, Aksoy OG, et al. Karpal tünel sendromu: Cerrahi tedavi izleminde fonksiyonel ve semptomatik skorlama. Acta Orthop Traumatol Turc 2001;35:147-51

25. Ware JE, Sherbourne CD. The MOS 36-item shor form healty survey. I. Conceptual Framework and item Selection, Med Care 1992;30(6):473-83.

26. Koçyiğit H, Aydemir Ö, Fisek G, et al. Kısa form-36'nın Türkçe versiyonunun güvenilirliği ve geçerliliği. İlaç ve Tedavi Dergisi 1999;12(2):102-6.

27. Buysse DJ, Reynolds CF, Monk TH, et al. The Pittsburgh sleep quality index: A new instrument for psychiatric practice and research. Journal of Psychiatric Research 1989;(28):193213.

28. Ağargün $M Y$, Kara $H$, Anlar O. Pittsburgh uyku kalitesi indeksinin geçerliği ve güvenirliği. Türk Psikiyatri Derg 1996; 7:107-15.

29 Afşar Si, Sarıfakıoğlu B, Akçay Yalbuzdağ Ş. Karpal tünel sendromu tedavisinde fizik tedavi modalitelerinin yeri: Derleme: Türk Osteoporoz Dergisi 2014;20:125-31.

30. Chang HY, Chou KY, Lin JJ, et al. Immediate effect of forearm Kinesio taping on maximal grip strength and force sense in healthy collegiate athletes. Phys Ther Sport 2010;11:122-7.

31. Arslan S, Karahan AY, Oncu F, et al. Diagnostic performance of superb microvascular imaging and other sonographic modalities in the assessment of lateral epicondylosis. J Ultrasound Med 2018;37(3):585-93.

32. Karahan AY, Yildirim P, Kucuksarac S, et al. Effect of kinesio taping on elbow muscle strength in healthy individuals: A randomized trial1. J Back Musculoskelet Rehabil 2017;30(2):317-23.

33. Karahan AY, Arslan S, Ordahan B, et al. Superb microvascular imaging of the median nerve in carpal tunnel syndrome: An electrodiagnostic and ultrasonographic study. J Ultrasound Med 2018;37(12):2855-61.

34. Manente G, Torrieri F, Di Blasio F, et al. An innovative hand brace for carpal tunnel syndrome: A randomized controlled trial. Muscle Nerve 2001;24:1020-5.

35. Yagcı I, Ucan H, Yılmaz L, et al. Karpal tünel sendromu 
tedavisinde splint, splint ile local steroid enjeksiyonu ve cerrahinin karşılaştırılması. Turk J Phys Med Rehab 2006;52(2):55-60.

36. Karakoyun A, Çalık Y. Üst ekstremite tuzak nöropatileri. Ege Tıp Bilimleri Dergisi 2019;2(1):42-7.
37. Ince B, Baycar Z, Çolak TS, et al. Karpal tünel sendromu cerrahi zamanlamasında EMG'nin rolü. Selcuk Med J 2019;35(2):90-3. 